\title{
Non-invasive Geological Methods for Solving Geotechnical Problems of Slope Stability: Case Study
}

Métodos geológicos no invasivos en la solución de problemas geotécnicos de estabilidad de taludes: Estudio de caso

\author{
Omar Antonio Guerrero ${ }^{1 *}$, Rosibeth Toro-Mora ${ }^{2}$, Omar Alejandro Guerrero-Camargo ${ }^{3}$ \\ ${ }^{1 *}$ MSc. in Geological Sciences, omarguerrero1231@gmail.com, Orcid: 0000-0002-8859-2906, Universidad de los Andes, Mérida, Venezuela. \\ ${ }^{2}$ MSc. in Hydrogeology, rosibeth@ula.ve, Orcid: 0000-0002-1252-3584, Universidad de los Andes, Mérida, Venezuela. \\ ${ }^{3}$ Spc. in Hydraulics, omarguerrerocamargo2@gmail.com, Orcid: 0000-0001-8377-1019, Universidad de los Andes, Mérida, Venezuela.
}

How to cite: O.A. Gerrero, R. Toro-Mora y O.A Guerrero-Camargo, "Non-invasive Geological Methods for Solving Geotechnical Problems of Slope Stability: Case Study”. Respuestas, vol. 24, no. 2, pp. 54-63, 2019.

Received on September 05, 2018; Approved on December 15, 2018

\begin{tabular}{|c|c|}
\hline & ABSTRACT \\
\hline $\begin{array}{l}\text { Hydrogeomorfology, } \\
\text { Water } \\
\text { Geochemistry, } \\
\text { Geophysics, } \\
\text { Slope stability. }\end{array}$ & $\begin{array}{l}\text { The soil geotechnical conditions for the foundation of civil structures are evaluated, through the application } \\
\text { of geophysical techniques (vertical electrical probes) and geochemical (analysis of stable isotopes of water), } \\
\text { to recognize the hydrogeological conditions of the subsoil. The dominant rocky substratum are clayey and } \\
\text { sandy phyllites of the Palmarito (Paleozoic - Permian) geologic unit; These rocks, when they decompose, } \\
\text { form clays, silts and sands from fine to very fine grains. The location site of the work is projected on } \\
\text { old deposits of alluvial fans (Quaternary) partially stabilized, with a mixture of gravel-silty gravel residual } \\
\text { soils (GC), with a thickness greater than } 15 \mathrm{~m} \text {. The measured groundwater levels }(2 \mathrm{~m} \text { ) correspond to a } \\
\text { discontinuous layer of fine to very fine saturated sand. Through geochemical and geophysical methods, } \\
\text { it was possible to know the distribution of groundwater for the design of the drainages and the surface of } \\
\text { the rotational sliding of the dry stratum superior to the phreatic level }(2 \mathrm{~m}) \text { is recognized. The corrective } \\
\text { stabilization of the slope allowed reaching safety factor values greater than or equal to }(\mathrm{FS}=1.5 \text { ) }\end{array}$ \\
\hline
\end{tabular}

\section{RESUMEN}

\section{Palabras clave:}

Hidrogeomorfología, Geoquímica del agua, Geofísica, Estabilidad de la pendiente.
Se evalúan las condiciones geotécnicas de suelos para la fundación de estructuras civiles, a través de la aplicación de técnicas geofísicas (Sondeos eléctricos verticales) y geoquímicos (análisis de isótopos estables de agua), para reconocer las condiciones hidrogeológicas del subsuelo. El sustrato rocoso dominante son filitas arcillas y arenosas de la unidad geológica Palmarito (Paleozoico - Pérmico); estas rocas al descomponerse forman arcillas, limos y arenas de grano fino a muy fino. El sitio de ubicación de la obra se proyecta sobre antiguos depósitos de abanicos aluviales (Cuaternarios) parcialmente estabilizados, con mezcla de suelos residuales gravo arcillosos-limosos (GC), con espesor mayor a $15 \mathrm{~m}$. Los niveles freáticos medidos $(2 \mathrm{~m})$, corresponden con un estrato discontinuo de arena de grano fino a muy fino saturada. A través de métodos geoquímicos y geofísico se pudo conocer la distribución de aguas subterráneas para el diseño de los drenajes y se reconoce la superficie del deslizamiento rotacional del estrato seco superior al nivel freático $(2 \mathrm{~m})$. Los correctivos de estabilización del talud permitió alcanzar valores de factor de seguridad superiores o iguales a $(\mathrm{FS}=1.5)$.

\section{Introduction}

The study area is located in an alluvial fan deposit with residual meteorised manto, in the middle geomorphological position of the alluvial fan and dense clayey gravel soils and under seismically active conditions [1]. The objective of the study is to determine the geology, geotechnics

*Corresponding author.

E-mail address: omarguerrero1231@gmail.com (Omar Antonio Guerrero)

(c) $(1) \Theta$ Peer review is the responsibility of the Universidad Francisco de Paula Santander.

cc) This is an article under the license CC BY-ND (http://creativecommons.org/licenses/by-nc-nd/4.0/) 
and geomechanical stability of the soil and its load-bearing capacity to design buildings. Field reconnaissance visits were carried out, complemented by the execution of calicatas located in such a way as to reflect the sedimentological and geomechanical characteristics of the soil [2]. Vertical electrical soundings (SEV) were also carried out to determine the depth of the water table, lateral and vertical extension of sediments in the soil profile, depth of soil-rock contact and surfaces of rupture of rotational slides in depth [3], [4]. The starting point was the establishment of a geologicalgeomorphological design that allowed the definition of patterns of sedimentary accommodation and recent sedimentation processes [5]. The location of the wetlands (streams, white and served water pipes, urban drainage) was determined through the evaluation of remote sensors (satellite images, maps and aerial photos), where it was possible to recognize localities of representative water sources and springs, which were the object of observations and measurements, which are a function of the relationships between the aforementioned factors and the geological-sedimentary aspects, at the same time the conditions of saturation or oversaturation that occurs on or near the surface of the soil were evaluated. The source zones and springs were evaluated geochemically through the determination of water isotopes (Deuterium and O18) [6] - [8] and slide ${ }^{\circledR}$ (free software) was applied to the geotechnical evaluation of the slopes.

\section{Study area}

The area under study is an area of $24 \mathrm{~km} 2$ located on the northern slope of the city of Merida, Mérida - Venezuela, between UTM coordinates N: 950300; E: 261085, altitude: 1540 masl (Figure 1). The area corresponds to the foothills of the Sierra de La Culata that extends in the NW-SE direction in the study area, in a stretch where there is evidence of slow movements of land mass, types of reptation and multiple retrogradant rotational landslides according to [3] and [4].

\section{Working method}

The method of work begins with the determination of the watershed division, through the application of free software (QGIS) in satellite images, aerial and topographic maps.
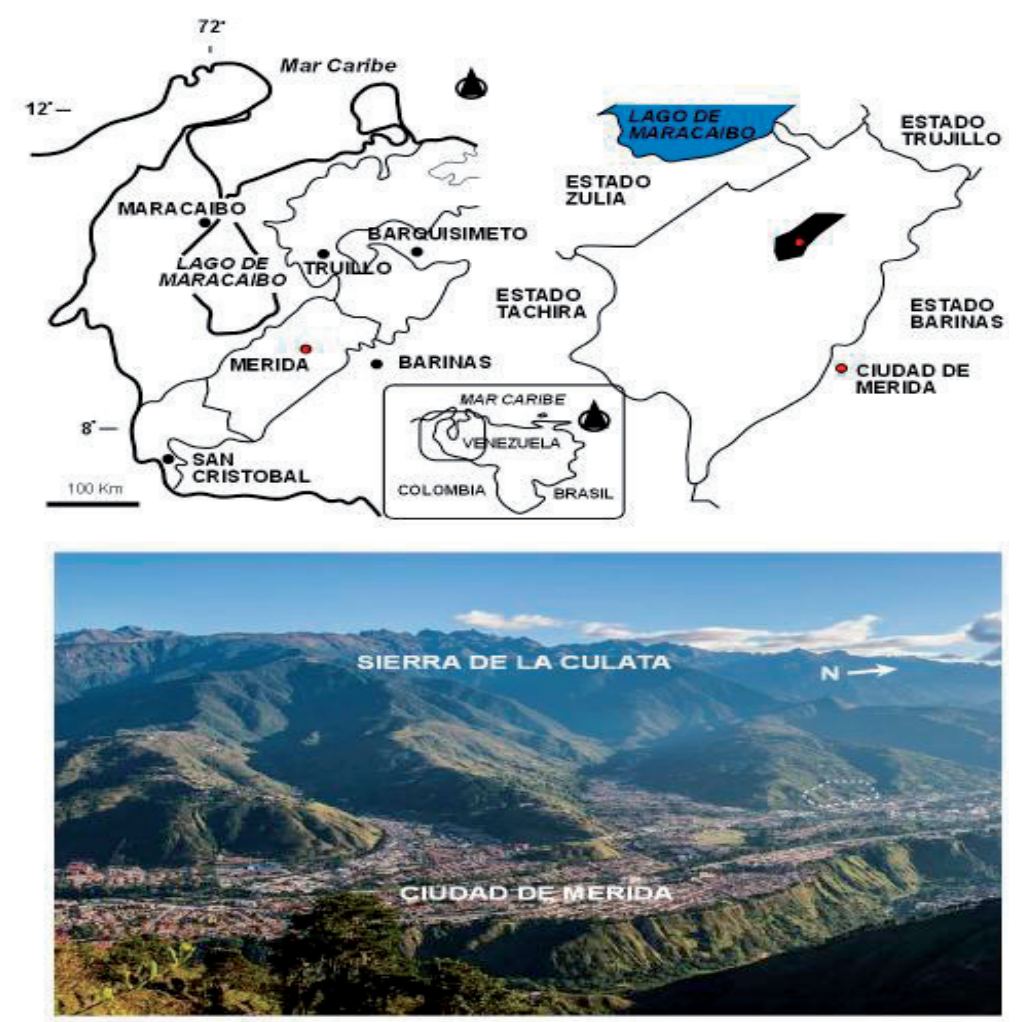

Figure 1. Study area located on the slope of Sierra de La Culata, in the town of Piedeltiro, Ciudad de Mérida 
morphometry of the micro watershed and proceeds to determine the average flows of streams and wetlands through the float method, obtaining samples of sediments and rocks from outcropping units to know the lithological and geomechanical compositions of sedimentary deposits and soils. The elaboration of vertical electric soundings (SEV), was used the Wenner's [9] arrangement, with the purpose of determining the phreatic level in the study area, using the Nilson resistivity meter of $12 \mathrm{~V}$ analogical.

The electrical resistivity ( $\rho$ ) of a material describes the difficulty encountered by the current as it passes through it. Similarly, conductivity $(\sigma)$ can be defined as the ease with which electrical current passes through the material. This method is characterized by the study of variations in the physical parameters of rocks or soils and depends on factors that affect the resistivity of materials, such as porosity, water in pores, conductivity in mineral grains, degree of compaction, etc [9]. The resistivity and conductivity of terrestrial materials are based on the application of Ohm's Law (V = IR) where $\mathrm{V}=$ voltage (Volts), I = current (Amps) and $\mathrm{R}=$ resistance $(\mathrm{Ohms})$. In practice, what is measured is the apparent resistivity, which is expressed (1)

$$
\begin{aligned}
& \rho=4 . \Pi \cdot A \cdot R /\left[1+\left[\left(2 \cdot A / A^{2}+4 \cdot B^{2}\right)^{0.5}\right]-\left[\left(2 \cdot A / 4 \cdot A^{2}+\right.\right.\right. \\
& \left.\left.4 . B^{2}\right)^{0.5}\right](1)
\end{aligned}
$$

\section{Where;}

$\rho$ is the average resistivity at depth (A)(ohm-m)

$A$ is the distance between electrodes $(m)$

$B$ is the burial depth of the electrodes $(m)$

\section{$R$ is the terrometer reading (ohms)}

Finally, a sample of water is taken from springs, streams and pipes in the dwellings located in the study areas, in order to carry out geochemical tests of stable isotopes, necessary to determine the source-spring relationship and locate the areas of leakage and migration of groundwater existing in the locality. The water samples were analyzed with respect to Standard Working of Los Gatos Research [6], [8], using a laser spectrometer for liquid water model DLT-100, the maximum deviation considered for the results is $2,0 \%$ o for deuterium and $0,3 \%$ for oxygen- 18 and the reported values is the average of at least two measurements made on non-consecutive days.

\section{Exploration results}

Topographically, the area is located on a slightly inclined (5\%) to inclined (35\%) surface, corresponding to areas of old alluvial fans slightly stabilized at the bottom of a river valley, the environment towards the NE-E (Pie del Tiro Sector) the slope is greater than $35 \%$ and reaches a maximum of $45 \%$, while in the SE direction (Sector Los Pinos), the slope decreases substantially to $2 \%$. Surface drainage runs in the SSW direction, in the direction of the natural slope, made up of three (3) streams, two (2) semipermanent and one (1) permanent, the latter being channelled through concrete caissons. Relatively far from the site of the land drains the stream La Gavidia, and secondary semi-permanent streams. For the date of the sampling (January 2016, dry subhumid month) a water table between $2.10 \mathrm{~m}$ and $3.30 \mathrm{~m}$ deep was visualized. According to the climatological station of Merida (Capital), the area is dominated by a wet mesothermic climate, with average annual rainfall of $1656 \mathrm{~mm}$, temperature of $19^{\circ} \mathrm{C}$ and evapotranspiration of $853 \mathrm{~mm}$. The precipitation has a bimodal behavior with maximums in the months of May and October, being the estimated surplus of $250 \mathrm{~mm}$ of water column and an annual average of $941.4 \mathrm{~mm}$ of annual average, it is to be noted that due to the climatic behavior the precipitations are of high intensity and frequency. The natural vegetation of the area has been totally intervened by means of traditional methods of pruning developed in the zone. For this reason, there is a tropical vegetation with highly developed tree species. vertical but very dispersed. This vegetation is more abundant along the existing streams in the terrain, as well as in the dams of the stream La Gaviria. It is recommended to plant vetiver and bamboo grasses along the streams. 

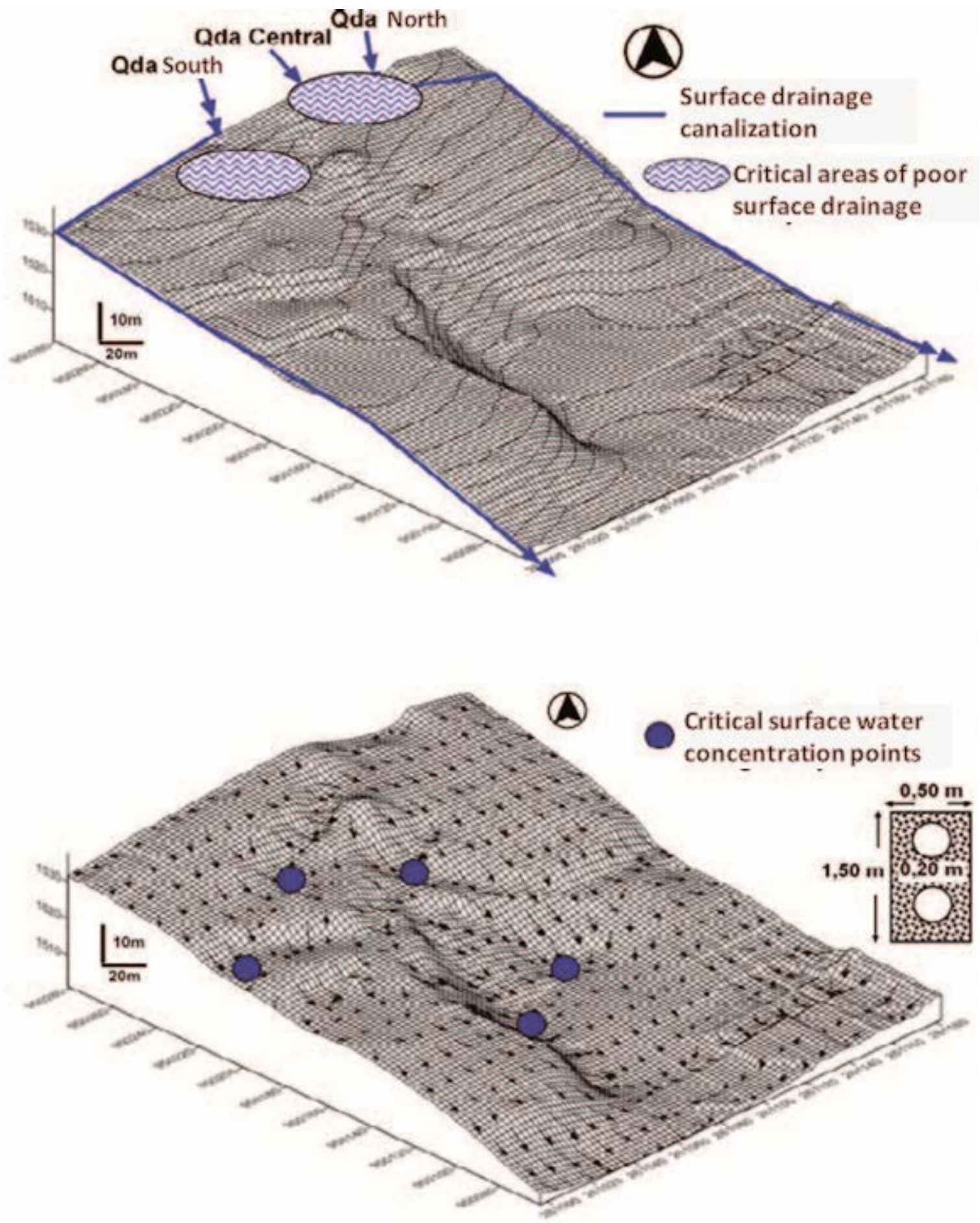

Figure 2. Main direction of surface runoff water and critical accumulation points, a drainage design is performed.

\section{Surface geology and geomorphology}

Physiographically, the study area is framed in the middle sub-basin of the Chama River, forming part of the foothills of the Sierra de La Culata Mountain Range, within the central valley of the Mérida Andes. The area is dominated by three main geoforms (Figure 3 ); the foothills of the slopes of the Sierra de La
Culata, composed of: a) Slightly metamorphic rocks of the Palmarito Formation, which in this locality are of the meta-sandstone and meta-lutite type; b) Accumulations of small coalescent alluvial fans and low hills bordering the geomorphic ensemble; and, c) Dispersed fluvial systems composed of permanent and semi-permanent streams. 


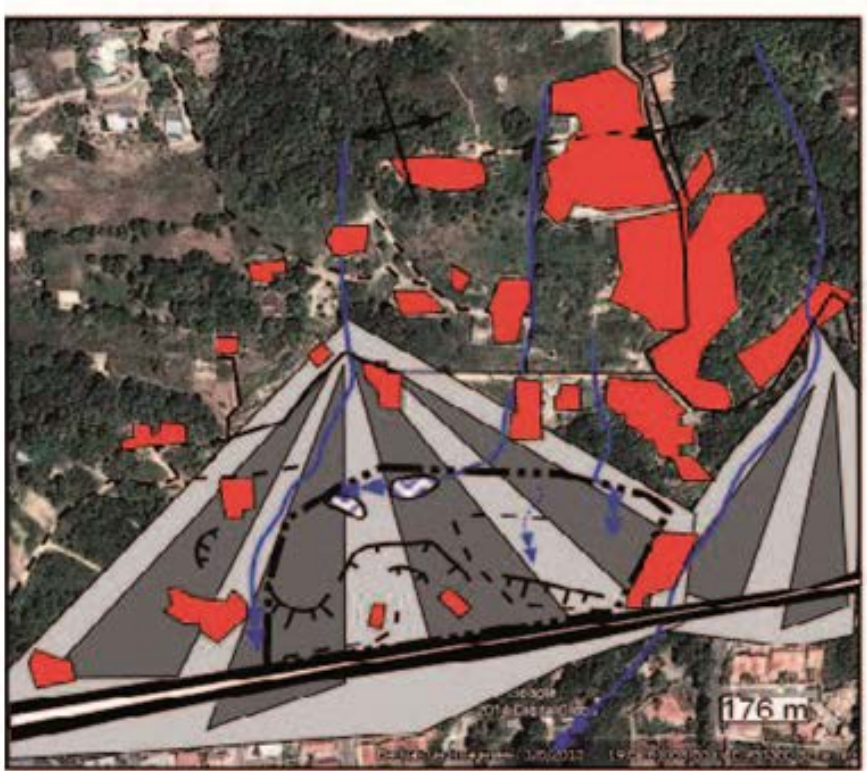

Image Google, 2013

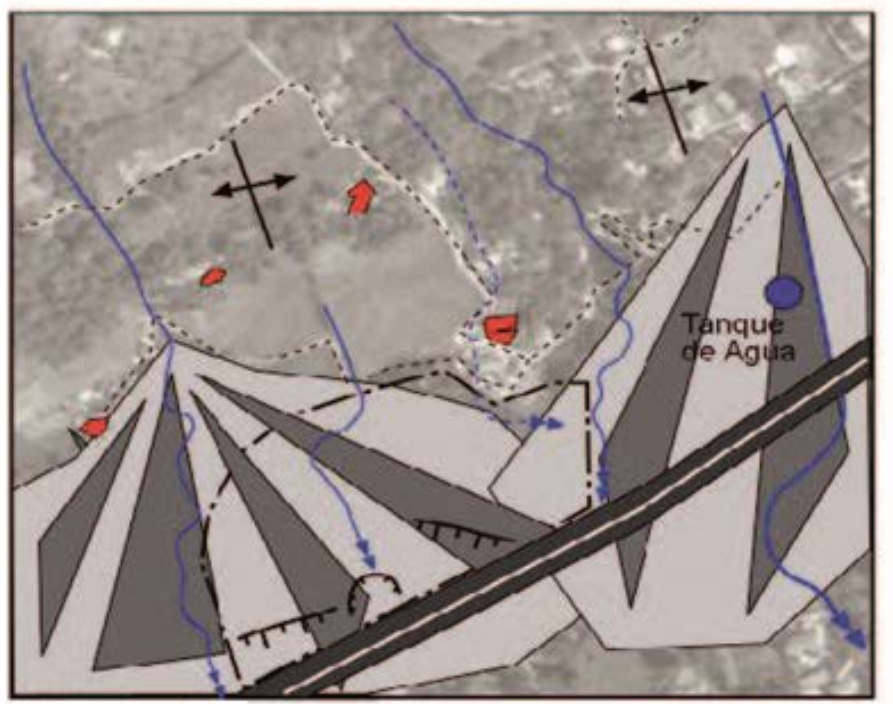

Air mission 010480. Vista 162.1983. i... Monte Bello land area

Alluvial fan

Urbanized area - houses

Anticline - water divide

Rotational sliding

Hillside - slope

Concentrated runoff (streams creeks)

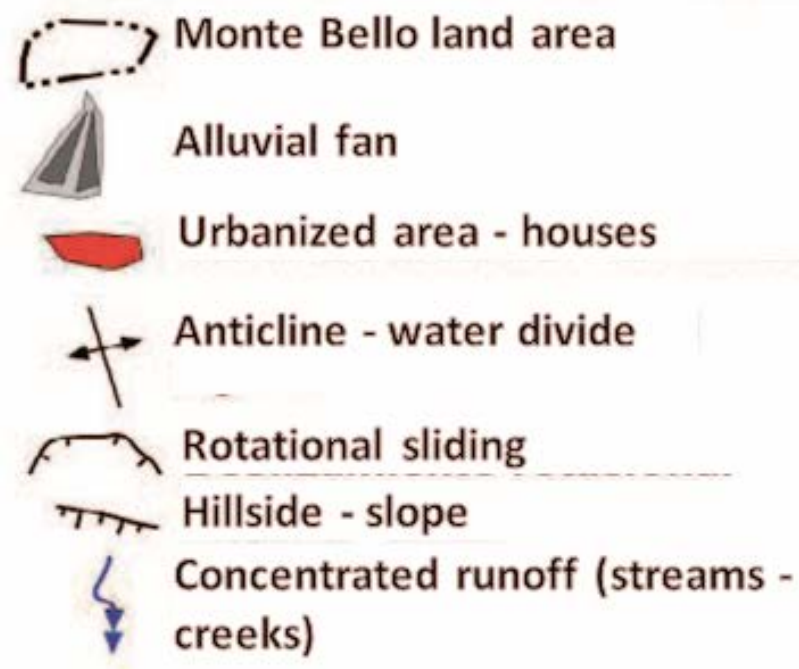

Figure 3. Satellite image (Google, 2013) and air mission 010480 (182, 1983), showing the relative location of the construction site and its local geomorphology Source: own

\section{Local geological description}

Calicatas (Figure 4) of $1.5 \mathrm{~m} \times 1.5 \mathrm{~m} \times 3 \mathrm{~m}$ were excavated, where continuous and massive thicknesses of gravel (cobbles and pebbles), medium to fine grain sands with important fine contents (silts and clays) were generally recognized, arranged in layers of at least $1 \mathrm{~m}$ thick and covered superficially by $80 \mathrm{~cm}$ of gravel-sandy filling material with scarce organic matter.

The profile of the calicata in all cases contains granular material from sand-loamy soils with abundant content of silty sands and scattered gravel (clasts up to $30 \mathrm{~cm}$ in diameter). They present in general the following characteristics; thicknesses of $0.10 \mathrm{~m}$ of clay soil - organic compost (CL) with scattered gravel, $0.70 \mathrm{~m}$ of quartz-micaceous gravelclay soil, although there is a domain of fragments (gravel) of phyllites and minor quartz, they constitute a mixture of fine sandy clay with scattered gravel (GC). 

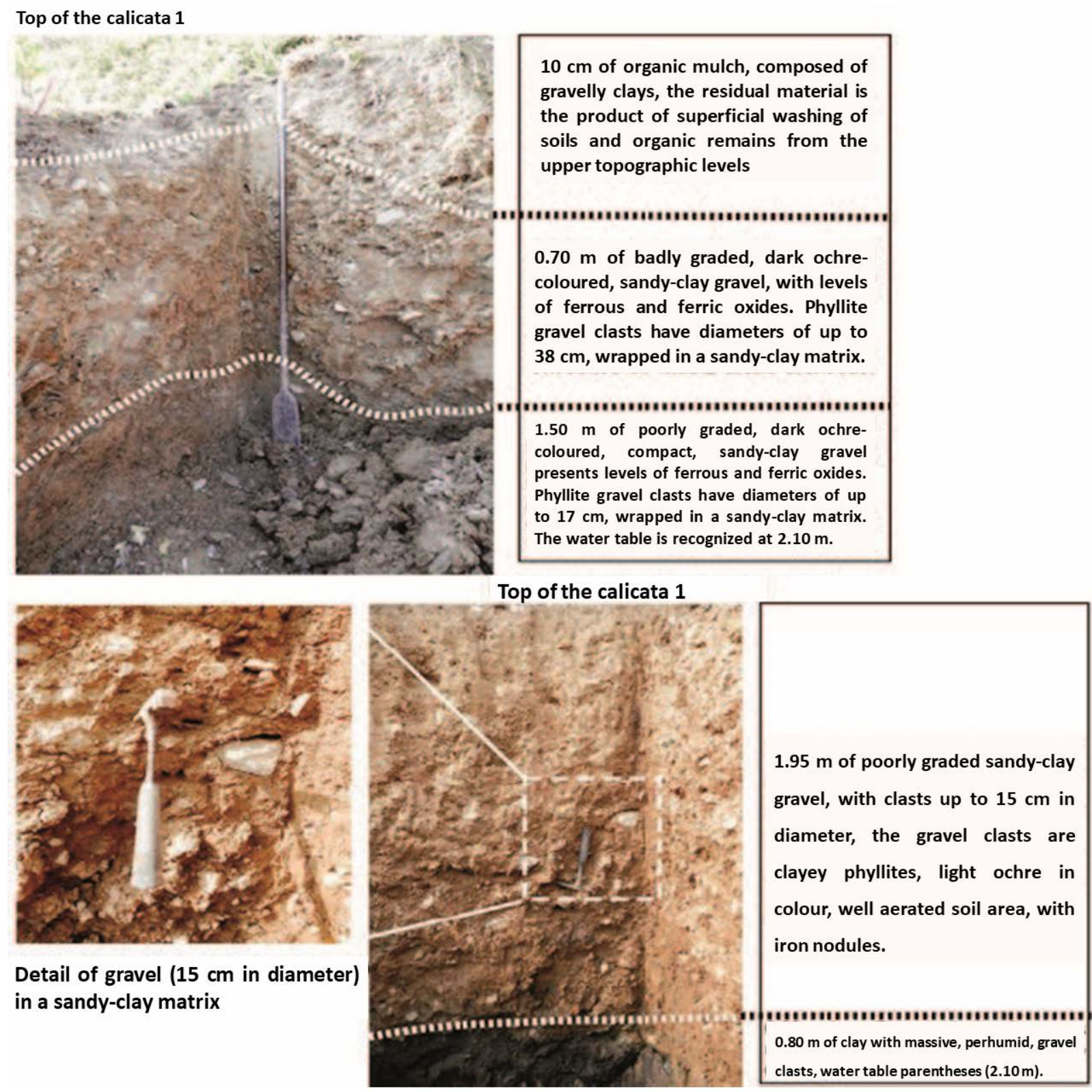

Figura 4. Descripción sedimentaria de los suelos en la calicata $\mathrm{C} 1$. Se reconocen niveles de suelos gravo arcillosos mal gradados (GC) y limo-areno arcillosos con gravas dispersas en la base (SP)

\section{Geophysical aspects (vertical electrical tests)}

Five (5) boreholes were conducted in periods with sporadic rainfall at the end of January 2016, and two (2) boreholes in the dry period (February 2016), to make the compensation and determine the real depth of the phreatic levels. The results determine water table depths between $2 \mathrm{~m}$ and $4.66 \mathrm{~m}$ during the rainy season and reach up to $8 \mathrm{~m}$ and $+10 \mathrm{~m}$ depth during the dry season (February).

The results of the geochemistry of water isotopes (Table 2, Figure 5) using the methodological procedures of [6] and [8], allowed us to recognize that the sumps sites correspond to the white water and sewage piping systems of the existing dwellings in the existing low areas adjacent to the study area, which suffered breakages due to landslide - soil reptation and partially with the lack of clogging or breakage of the existing streams, due to this we proceeded to correct the pipes of homes with water loss problems and hydraulic corrections of the infiltration areas of the streams in order to reduce the times of concentration and therefore increase the speed of flow transit. 
Table I. Sounding results show the interpretation of soil sediments and water table (nf) for each sounding point

\begin{tabular}{|c|c|c|c|c|c|}
\hline $\begin{array}{l}\text { Thicknes- } \\
\text { ses (m) }\end{array}$ & SEV 1 & SEV 2 & SEV 3 & SEV 4 & SEV 5 \\
\hline 0.67 & $\begin{array}{c}\text { saturated fine grain } \\
\text { sands }\end{array}$ & sands & gravel & gravel & clays \\
\hline 1 & sands & rock & $\begin{array}{l}\text { saturated fine } \\
\text { grain sands (nf) }\end{array}$ & silts & silts \\
\hline 1.33 & silts & silts & silts & silts & silts \\
\hline 2 & $\begin{array}{l}\text { saturated fine grain } \\
\text { sands (nf) }\end{array}$ & $\begin{array}{l}\text { saturated fine grain } \\
\text { sands (nf) }\end{array}$ & gravel & silts & $\mathrm{nf}$ \\
\hline 2.66 & rock & $\begin{array}{l}\text { saturated fine grain } \\
\text { sands (nf) }\end{array}$ & silts & silts & $\mathrm{nf}$ \\
\hline 3.33 & $\begin{array}{l}\text { saturated fine grain } \\
\text { sands (nf) }\end{array}$ & gravel & silts & $\begin{array}{l}\text { saturated } \\
\text { fine grain } \\
\text { sands (nf) }\end{array}$ & $\mathrm{nf}$ \\
\hline 4.66 & silts & sands & $\begin{array}{l}\text { saturated fine } \\
\text { grain sands (nf) }\end{array}$ & gravel & $\begin{array}{c}\text { saturated fine } \\
\text { grain sands } \\
\text { (nf) }\end{array}$ \\
\hline 6.66 & sands & gravel & rock & silts & clays \\
\hline 7.33 & sands & rock & sands & silts & silts \\
\hline
\end{tabular}

Table II. Average isotopic characteristics of water samples from spring areas (streams), dwellings and springs

\begin{tabular}{|c|c|c|c|c|}
\hline $\begin{array}{l}\text { IDENTIFICATION } \\
\text { SAMPLE }\end{array}$ & $\begin{array}{c}\mathrm{d}^{2} \mathrm{H} \% \text { o } \\
\text { Reportable } \\
\text { value (per } \\
\text { thousand) }\end{array}$ & $\begin{array}{c}\mathbf{d}^{2} \mathbf{H} \% \\
\text { Standard } \\
\text { Deviation }\end{array}$ & $\begin{array}{c}\frac{\mathrm{d}^{18} \mathrm{O} \%}{\text { Reportable }} \\
\text { value (per } \\
\text { thousand) }\end{array}$ & $\begin{array}{l}\frac{\mathrm{d}^{18} \mathrm{O} \%}{\text { Standard }} \\
\underline{\text { Deviation }}\end{array}$ \\
\hline E1__Home Faucet & $-98,57$ & 0,78 & $-15,33$ & 0,41 \\
\hline E2- Stream & $-128,23$ & 1,30 & $-17,80$ & 0,32 \\
\hline E3- Stream & $-132,23$ & 1,50 & $-19,50$ & 0,40 \\
\hline E4- Stream & $-137,23$ & 1,42 & $-19,50$ & 0,39 \\
\hline E5 - Spring & $-92,93$ & 0,89 & $-13,86$ & 0,33 \\
\hline E6 - Spring & $-95,93$ & 0,64 & $-14,86$ & 0,31 \\
\hline
\end{tabular}

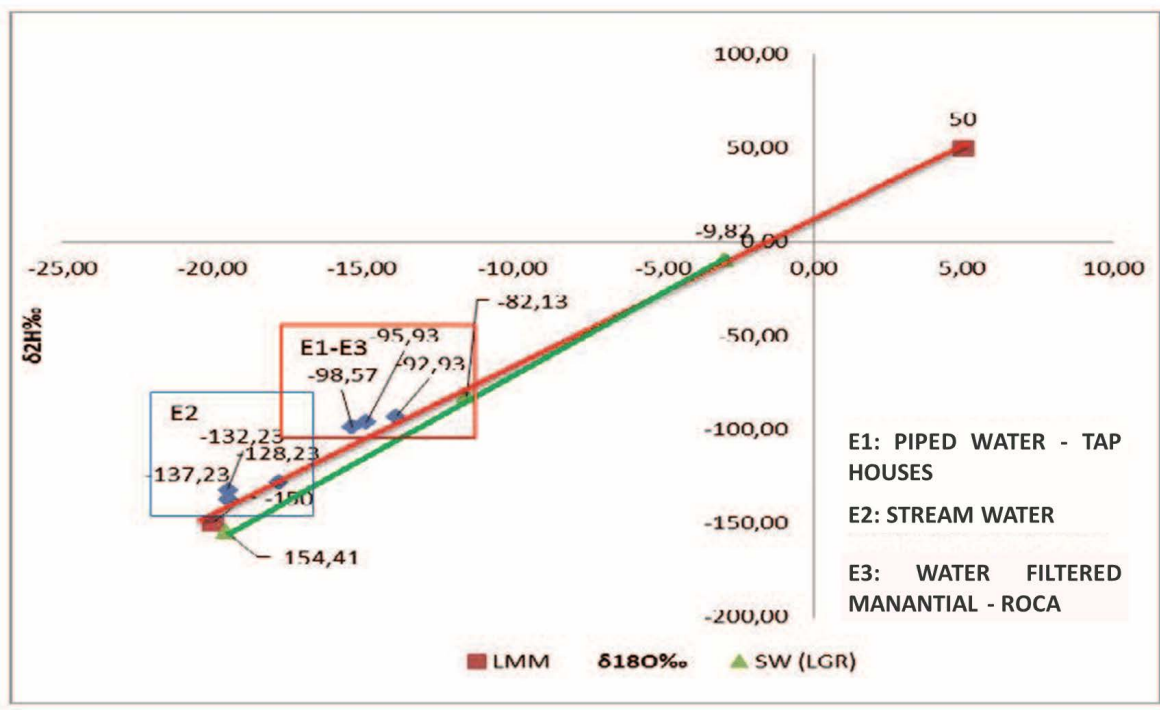

Figure 5. Isotopic distribution of water samples with respect to the World Meteorological Line (LMM, in red line) and Regional (LGR in green)

Finally, through the integration of the geophysical, geochemical and hydrogeomorphological aspects of the area, hydrogeomorphological profiles are elaborated showing the values of the water table and eventual areas of detachment of the rotational slip masses, necessary to design the civil works that allow their geotechnical stabilization (Figure 6). 


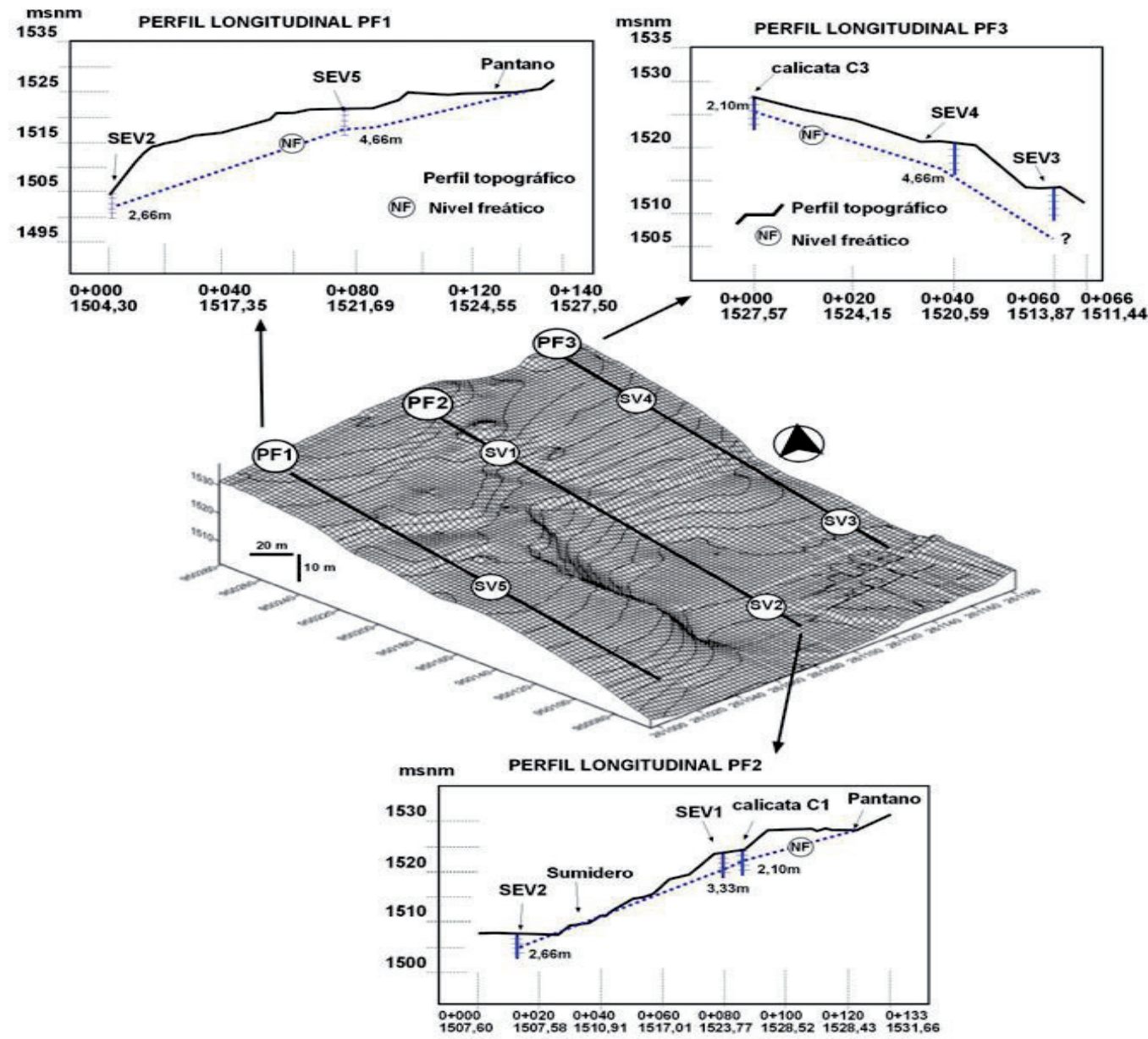

Figure 6. Longitudinal hydrogeomorphological sections (black line) and depth of water table (blue dotted line), for the wet period (December 2014), for the dry period (February, 2015) the values of $\mathrm{nf}>7.33$ in the whole terrain

\section{Geotechnical aspects of slopes}

For a better evaluation of the natural slopes, the terrain was divided into three slope sections (Figures 7, 8 and 9), the first (PF1) corresponds to the southern section of the terrain, the second (PF2) corresponds to the central section and the third (PF3) to the northern section, because the three sections have different geomorphological and geotechnical behaviours.

\section{Geotechnical response of the southern slope section of the terrain (PF1)}

the natural slope conditions, under water table conditions at 2,10 and 4,66 m, the slope remains stable without load and with natural topography, reaches $\mathrm{FS}$ values of 1,1 . If we lower the water table to values between $4 \mathrm{~m}$ at the head of the slope and 6 $\mathrm{m}$ at the base, we obtain FS: 1,236, without applying load.

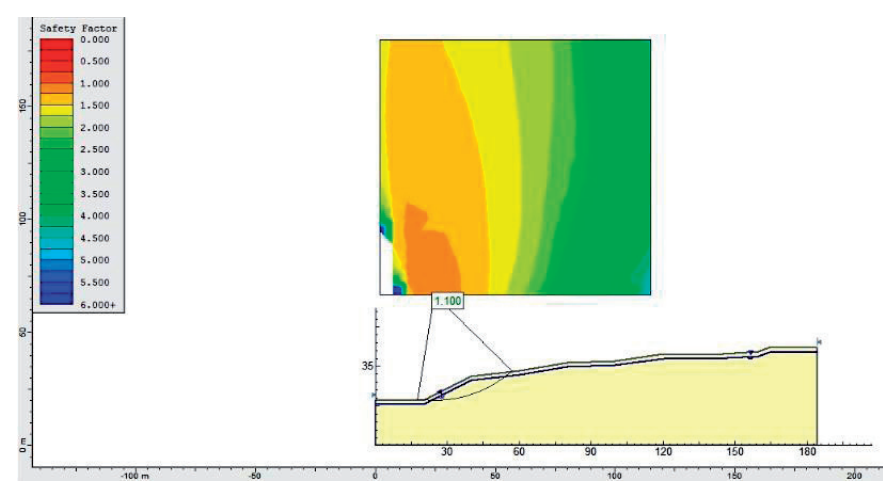

Figure 7. Assessment of the geotechnical safety factor of the southern slope (PF1) under water table conditions and current topographic profile, unmodified and unladen.

\section{Geotechnical response of the slope central section of the terrain (PF2)}

For the central section of the topographic cut ground PF2, without topographic modifications and phreatic levels of $2,10 \mathrm{~m}$ and $3,33 \mathrm{~m}$, without applying bearing load, the FS is 1,130 . When we carry out 
a deepening of the water table to $4 \mathrm{~m}$ head and 6 $\mathrm{m}$ at the foot of slope, without modifications of the topography the FS is 1.207 . When we carry out a deepening of the water table to $4 \mathrm{~m}$ head and $6 \mathrm{~m}$ at the foot of slope, without modifications of the topography the FS is 1.207 .

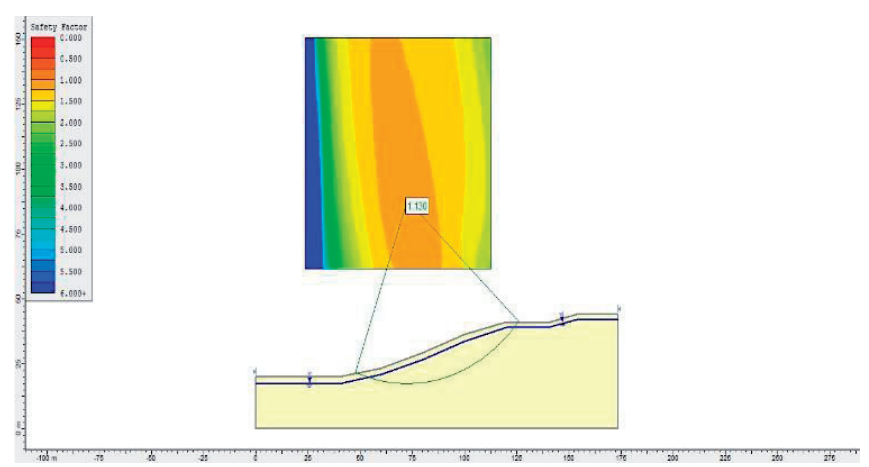

Figure 8. Assessment of the geotechnical safety factor of the central slope (PF2) under groundwater conditions and current topographic profile, unchanged and without load.

\section{Geotechnical response of the slope, northern section of the terrain (PF3)}

this slope profile is more stable than the previous ones, obtaining in natural conditions the topography and water table at $3.10 \mathrm{~m}$ and $3.33 \mathrm{~m}$ (measured in the field), geotechnical safety factor of 1,432, if load bearing application. If we reduce the water table to 4 $\mathrm{m}$ at the head and $6 \mathrm{~m}$ at the foot of the slope under normal topographic conditions, the geotechnical safety factor FS: 2,225 (Figure 8).

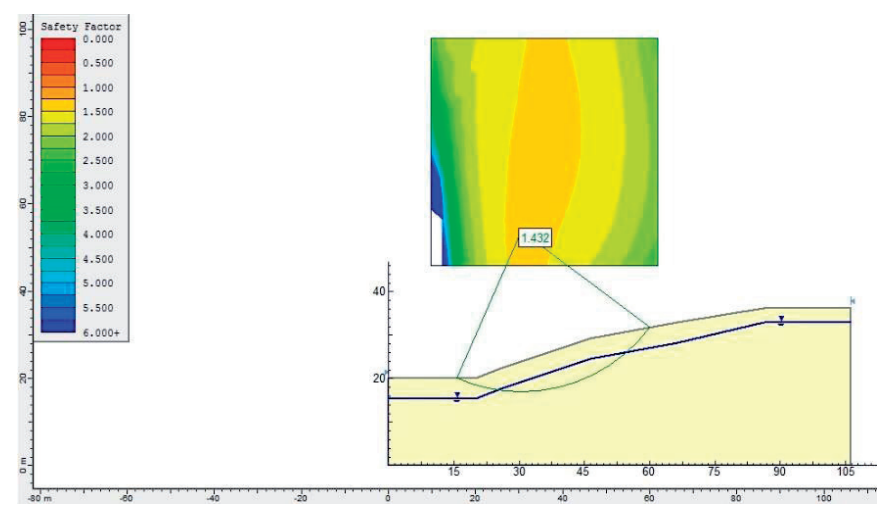

Figure 9. Assessment of the geotechnical safety factor of the northern slope (PF3) under groundwater conditions and current topographic profile, unmodified and unladen. Source: Own

From the integration of geotechnical results, geochemical tests of water in the search for the source-spring relationship and the procedure of vertical electrical soundings (SEV), it was possible to determine the phreatic levels at depths greater than $4 \mathrm{~m}$, as well as the preferential direction of this underground drainage, a model is proposed for the design of surface and subsurface drainage of the soil to stabilize the hydrogeomorphological processes of the area (Figure 10), especially the reptation and
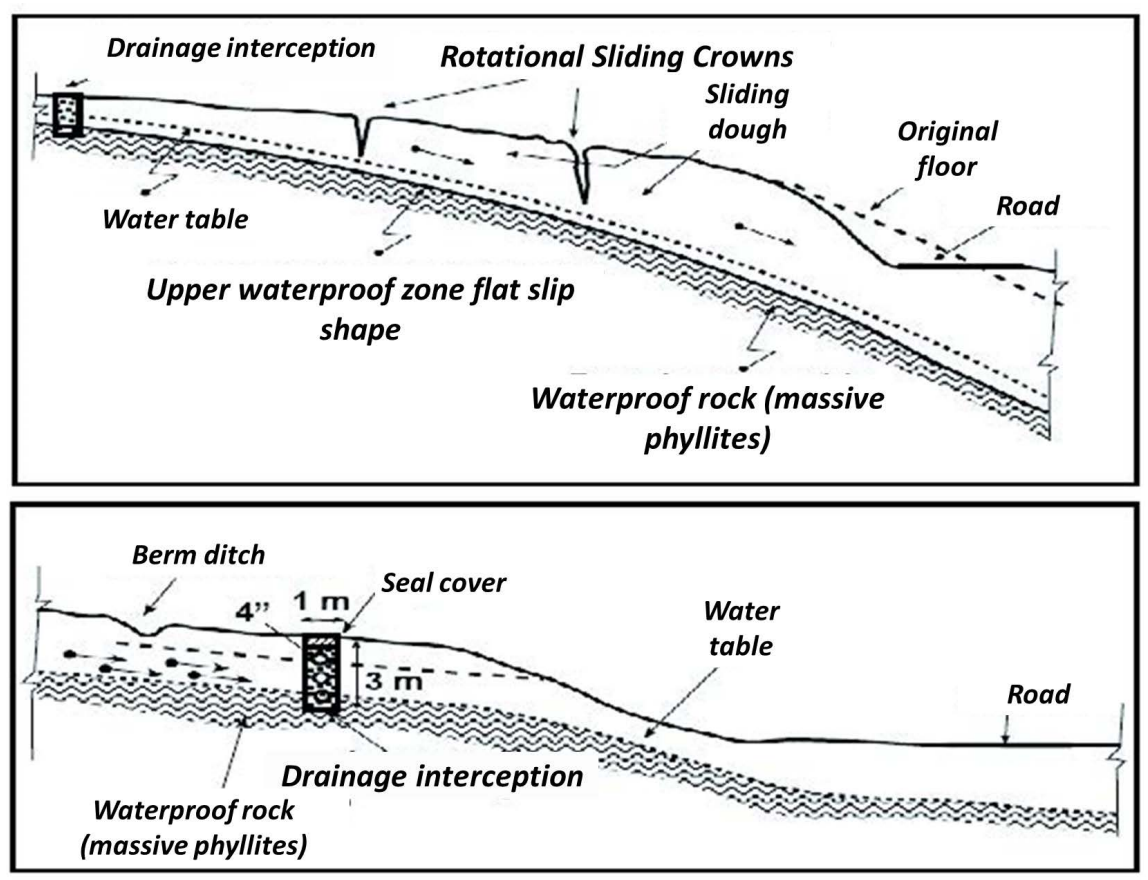

Figure 10. Diagram of the hydrogeomorphological conditions of the assessed slopes and drainage design proposal. 
rotational mass movements. And the proposal to carry out piles at depths of $15 \mathrm{~m}$., at the base of the sliding masses.

\section{Acknowledgement}

To the CDCHT of the Universidad de los Andes for its valuable financial contribution to the FI-28132-1 project and to Dr. Rosendo Camargo for his collaboration and guidance in the field.

\section{Conclusions}

The evaluated study area corresponds to deposits of alluvial fans (Quaternaries) partially stabilized, with a mixture of gravelly clayey-loamy residual soils (GC), with a thickness greater than $15 \mathrm{~m}$. The study area corresponds to deposits of alluvial fans (Quaternaries) partially stabilized, with a mixture of gravelly clayey-loamy residual soils (GC), with a thickness greater than $15 \mathrm{~m}$.

The geological and geomorphological structures offer partial risks to the infrastructure, if the phreatic levels are not controlled, which must remain below 4 to $6 \mathrm{~m}$ depth, in all the land. The development of a good rainwater drainage system is considered necessary due to the high intensity and frequency of rainfall.

The values of the safety factors are increased above FS: 1, when bermas are established with an inclination of $30^{\circ}$, and the phreatic levels are maintained at values of $4 \mathrm{~m}$ at the head and $6 \mathrm{~m}$ at the foot of the measured slopes, with load-bearing loads of $2 \mathrm{ton} / \mathrm{m}$. The values of the safety factors are increased above FS: 1, when bermas are established with an inclination of $30^{\circ}$, and the phreatic levels are maintained at values of $4 \mathrm{~m}$ at the head and $6 \mathrm{~m}$ at the foot of the measured slopes, with load-bearing loads of 2 ton $/ \mathrm{m}$. The possibility of increasing this load is subject to the design of the retaining walls and their depth, as well as the design of the drains.

\section{References}

[1] FUNVISIS - MINDUR. "Norma Venezolana: Edificaciones antisísmicas", Normas Covenin, 1756-80.82. 2002.
[2] J. Bowles, "Foundation analysis and design. New York", Cambridge University Press, 1982.

[3] J. Corominas, R. Copons, J. M. Vilaplana, J. Altimir and J. Amigó, "Integrated Landslide Susceptibility Analysis and Hazard Assessment in the Principality of Andorra", Natural Hazards, vol. 30, pp. 421-435, 2003.

[4] D. Cruden and D. Varnes, "Slope movement, types and processes", National Research Council, Washington. DC. USA. 1995.

[5] I. Casteletti, "Nociones de Mecánica de Suelos", Talleres Gráficos Universitarios, ULA, 2000.

[6] Q. F. Bécher, M. T. Blarasin and H. O. Panarello, "Modelado geoquímico e isotópico de las relaciones agua superficial-subterránea en la planicie arenosa del sur de Córdoba", Revista de la Asociación Geológica Argentina, vol. 72, no. 4, pp. 87-95, 2015.

[7] V. Chow, "Hydrologic determination of waterway areas for drainage structures in small drainage basins", The Texas A\&M Engineering Experiment Station, no. 462, pp. 198- 211, 1962.

[8] I. Clark and P. Fritz, "Environmental Isotopes in Hydrogeology”, Conciencia Sísmica, vol. 68. no. 5, pp. 384-393, 1997.

[9] R. González, D. Useche, D. Sánchez and O. Guerrero, "Hidrogeomorfológica del Sistema de Humedales de las Microcuencas La Sucia, Platanillo y La Honda: Determinación de Cantidad y Calidad de Agua. Parroquia Chaguará - Municipio Sucre, estado Mérida", Revista Ciencia e Ingeniería, vol. 37, no. 3, pp. 37-44, 2017. 